\title{
Use of psychoactive substances at least once in life among Brazilian university students at the beginning and end of courses and the associated factors
}

\author{
Uso de substâncias psicoativas pelo menos uma vez na \\ vida entre estudantes universitários brasileiros no início e \\ no final dos cursos e fatores associados
}

\author{
Laíza Rocha Dantas ${ }^{1}$, Monalisa Cesarino Gomes ${ }^{1}$, Larissa Chaves Morais de Lima1', \\ Bruno Rafael Cruz-da-Silva ${ }^{1}$, Lívia Rocha Dantas ${ }^{1}$, Ana Flávia Granville-Garcia ${ }^{1}$
}

\begin{abstract}
Objective: Investigate the use of psychoactive substances at least once in life among students at the beginning and end of their courses and determine the associated factors. Methods: A cross-sectional study conducted with a representative sample of 398 students in public university. The students answered a questionnaire validated for the evaluation of drug use and socio-demographic data. Poisson regression analysis was performed. Results: A total of $56.3 \%$ and $13.3 \%$ of the students had used both legal and ilegal drugs. The following variables remained significantly associated with legal drug use in the final model: male sex (PR=1.48; 95\% $\mathrm{Cl}: 1.25-1.76)$, older age group ( $\mathrm{PR}=1.23 ; 95 \% \mathrm{Cl}$ : 1.03-1.47), not living with parents $(\mathrm{PR}=1.20 ; 95 \% \mathrm{Cl}: 1.01-1.41)$, not having a religion ( $\mathrm{PR}=1.37$; $95 \% \mathrm{Cl}: 1.16-1.62)$ and taking a course in the health field ( $\mathrm{PR}=1.33 ; 95 \% \mathrm{Cl}: 1.08-1.64)$. The following variables were significantly associated with ilegal drug use: male sex ( $\mathrm{PR}=2.33 ; 95 \% \mathrm{Cl}: 1.35-4.02)$, older age group ( $\mathrm{PR}=2.27$; 95\%Cl: 1.28-4.02), higher monthly income (PR=1.73; 95\%Cl: 1.05-2.85) and not having a religion ( $P R=1.70 ; 95 \% \mathrm{Cl}: 1.02-2.84)$. Conclusion: Legal and ilegal drug use at least once in life was associated with social factors, sex, age, income, religion, living situation and type of higher education course. Keywords: alcohol drinking; smoking; street drugs; students.
\end{abstract}

\footnotetext{
Resumo

Objetivo: Investigar o uso de substâncias psicoativas, pelo menos uma vez na vida, entre os alunos no início e no final de seus cursos e determinar os fatores associados. Métodos: Estudo transversal com amostra representativa de 398 alunos de uma universidade pública. Os alunos responderam a um questionário validado para a avaliação do uso de drogas e tiveram dados sociodemográficos coletados. A análise de regressão de Poisson foi realizada. Resultados: Dos estudantes, 56,3 e 13,3\% utilizaram drogas lícitas e ilícitas, respectivamente. As seguintes variáveis permaneceram significativamente associadas ao uso de drogas lícitas no modelo final: sexo masculino ( $R P=1,48$; IC95\%: 1,25-1,76), faixa etária mais avançada ( $R P=1,23 ; I C 95 \%: 1,03-1,47)$, não residir na casa dos pais ( $R P=1,20$; IC95\%: 1,01-1,41), não ter religião ( $R P=1,37$; IC95\%: 1,16-1,62) e cursar área da saúde ( $R P=1,33 ;$ IC95\%: 1,08-1,64). As seguintes variáveis foram significativamente associadas ao uso de drogas ilícitas: sexo masculino ( $R P=2,33 ;$ IC 95\%: 1,35-4,02),

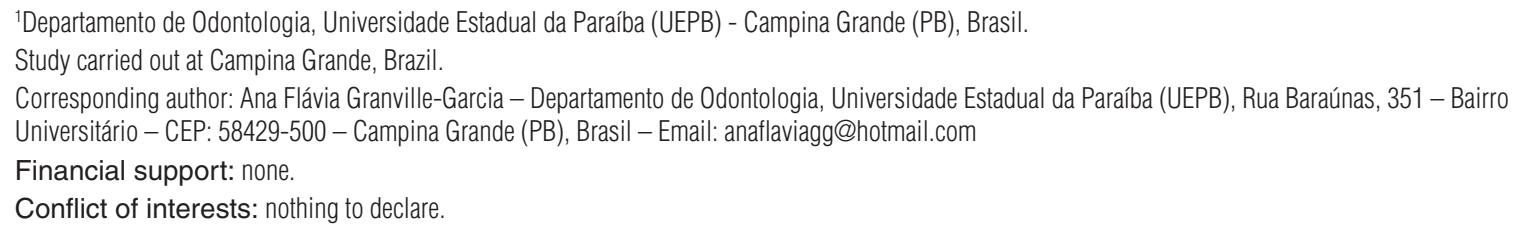


faixa etária mais avançada (RP=2,27; IC95\%: 1,28-4,02), maior renda mensal ( $R P=1,73$; IC95\%: 1,05-2,85) e não ter uma religião (RP=1,70; IC95\%: 1,02-2,84). Conclusão: O uso de drogas lícitas e ilícitas, pelo menos uma vez na vida, foi associado a fatores sociais, sexo, idade, renda, religião, situação de vida e tipo de ensino superior.

Palavras-chave: álcool; tabagismo; droga ilícita; estudantes.

\section{INTRODUCTION}

The consumption of psychoactive substances is quite common among university students and varies from occasional use to dependence ${ }^{1,2}$. Thus, drug use has become a worldwide concern in recent decades due to the high incidence and association with risk behaviors, which can have serious consequences to health ${ }^{3}$. The prevention of drug use is essential, as abuse and dependence are public health problems that contribute to the increase in expenditures on medical treatment and hospitalization and play an important role in traffic accidents, urban violence and premature deaths ${ }^{3}$.

Knowledge on what population groups are associated with the use of psychoactive substances is necessary to the establishment of drug prevention programs based on reliable data from epidemiological studies, thereby allowing health policies to be directed in a more effective manner ${ }^{4}$. Previous studies have found a relationship between the male sex and older age with an increased consumption of drugs ${ }^{2,5}$. However, this relationship needs to be further clarified with regard to the early consumption of drugs.

Upon entering the university environment, many young adults experience a set of changes in their daily lives, such as distance from their families, the formation of new friendships, greater independence and greater responsibility in the form of academic expectations ${ }^{6}$. This new situation can exert an influence on one's health, especially with regard to drug use, as such factors can play either a protective role or increase the risk of using such substances ${ }^{5,6}$. A previous study reports that students in the first year of university are at greater risk of experiencing the consequences of alcohol use, as they are often individuals who did not regularly drink alcoholic beverages in high school and began such use in the first year of their undergraduate education ${ }^{7}$. However, no studies have evaluated use of legal and street drugs in students the beginning and end of their courses. Moreover, most studies have evaluated the consumption pattern found in specific courses, whereas the present investigation offers an evaluation of students in different fields of knowledge. Other aspects also need to be explored in addition to course issues. Socioeconomic position and religion are examples, as they may act as confounders in this relationship.

The aim of the present study was to investigate the use of licit and illicit psychoactive substances at least once in life in a representative sample of Brazilian university students at the beginning and end of their courses and determine associated factors.

\section{METHODS}

\section{Study population}

A cross-sectional study was conducted with a representative sample of students at the State University of Paraíba (Brazil) in 2014. The sample size was calculated considering a 5\% acceptable error, 95\% confidence level, a population sample of 1632 students and an estimated prevalence rate of $50 \%$. The minimum sample was determined to be 312 students, to which $20 \%$ was added to compensate for possible dropouts, leading to 374 students. Due to the rounded figures in each course, the sample comprised 400 students. Students were selected from all courses of the Campus I of Universidade Estadual da Paraíba, which has the highest number and variety of courses. In order to be included, students had to be on the first or last semester of the course. Students of these semesters were selected through a simple random draw, proportionally to the size of the course in relation to the total number of students in the campus. Classes are offered in the morning, afternoon and at night on the following areas: biological sciences, physical education, nursing, pharmacy, physical therapy, dentistry, psychology, management, accounting sciences, social communication, statistics, mathematics, chemistry, sanitary and environmental engineering, physics, computer sciences, philosophy, geography, history, languages, pedagogy, sociology and law.

\section{Pilot study}

A pilot study was conducted to test the methodology and comprehension of the questionnaires. The university students in the pilot study $(n=40)$ were not included in the main sample. The "face validation" method was performed with $10 \%$ of the respondents to assess the participants' understanding of the responses. For such, the researchers asked the participants to explain in their own words what they understood for each item ${ }^{8}$. As there were no misunderstandings regarding the questionnaires or the methodology, no changes to the data collection process were deemed necessary.

\section{Data collection}

After receiving clarifications regarding the objectives of the study, the participants signed a statement of informed consent. Data collection involved the administration of the Alcohol, Smoking and Substance Involvement Screening Test (ASSIST), which was created by the World Health Organization ${ }^{9}$ and 
has been validated ${ }^{10}$. The ASSIST contains eight questions on the use of nine classes of psychoactive substances (tobacco, alcohol, marijuana, cocaine, stimulants, sedatives, inhalants, hallucinogens and opiates). The questions address frequency of use in one's lifetime as well as in the previous three months, problems related to use, concerns regarding use on the part of individuals close to the user, negative impacts on the execution of expected tasks, unsuccessful attempts to quit or cut down on use, compulsive feelings and the use of injectable substances. Each item has response options corresponding scores. For tobacco and street drugs, a score of 0 to 3 points was considered indicative of occasional use, a score of 4 to 26 points was indicative of hazardous use/abuse and a score of $\geq 27$ points was suggestive of dependence. For alcohol, a score of 0 to 10 points was considered indicative of occasional use, a score of 11 to 26 points was indicative of hazardous use/abuse and a score of $\geq 27$ points was suggestive of dependence ${ }^{10}$. For the present study, the variable was dichotomized for lifetime use (the use of a legal and/or street drug at least once in life).

The following socio-demographic characteristics were also collected: gender, age group, marital status, ethnicity, paid work, living situation (residing with or without parents), course in which the student is enrolled, part of the day in which classes are concentrated, period of the course and religion. The questionnaires were administered in the classroom setting and anonymity was ensured.

\section{Statistical analysis}

Descriptive and inferential statistics were conducted. Bivariate and multivariate Poisson regression analyses with robust variance were performed to determine the strength of associations between the independent variables and the use of legal and street drugs at least once in life $(\mathrm{p}<0.05)$. The Statistical Package for Social Sciences (SPSS for Windows, version 20.0, SPSS Inc, Chicago, IL, USA) was used for the statistical analyses.

\section{Ethical considerations}

The present study received approval from the Human Research Ethics Committee of the State University of Paraíba (process number 34161214.7.0000.5187) in compliance with Resolution 466/2012 of the Brazilian National Health Council. All participants read and signed a statement of informed consent.

\section{RESULTS}

A total of 398 university students participated in the present study, corresponding to $99.5 \%$ of the total determined by the sample calculation. The loss of two students was due to incomplete questionnaires. A total of $56.3 \%$ reported having experimented with legal drugs at least once in life and $13.3 \%$ reported having experimented with street drugs. Regarding legal drugs, $54.3 \%$ of the students reported having used alcohol some time in life and $20.4 \%$ reported using tobacco. Among street drugs, marijuana was the most prevalent, with $10.6 \%$ of the students reporting having used this drug at least once in life (Table 1).

Tables 2 and 3 display the results of the Poisson regression analyses for the use of legal and street drugs at least once in life according to the independent variables. The following variables were significantly associated with legal drug use: the male sex ( $\mathrm{PR}=1.48 ; 95 \% \mathrm{CI}: 1.25$ to 1.76 ), an older age group ( $\mathrm{PR}=1.23 ; 95 \% \mathrm{CI}: 1.03$ to 1.47$)$, not residing in the parents' home ( $\mathrm{PR}=1.20 ; 95 \% \mathrm{CI}: 1.01$ to 1.41$)$, not having a religion $(\mathrm{PR}=1.37 ; 95 \% \mathrm{CI}: 1.16$ to 1.62$)$ and taking a course in the health field ( $\mathrm{PR}=1.33$; 95\% CI: 1.08 to 1.64). The following variables were significantly associated with street drug use: the male sex ( $\mathrm{PR}=2.33$; 95\% CI: 1.35 to 4.02$)$, an older age group ( $\mathrm{PR}=2.27 ; 95 \% \mathrm{CI}: 1.28$ to 4.02$)$, a higher monthly income $(\mathrm{PR}=1.73 ; 95 \% \mathrm{CI}: 1.05$ to 2.85$)$ and not having a religion $(\mathrm{PR}=1.70$; 95\% CI: 1.02 to 2.84$)$.

Table 1. Frequency of legal and street drug use among university students

\begin{tabular}{|c|c|}
\hline Variable & $\begin{array}{c}\text { Frequency } \\
\mathbf{n}(\%)\end{array}$ \\
\hline \multicolumn{2}{|l|}{ Alcohol } \\
\hline Yes & $216(54.3)$ \\
\hline No & $182(45.7)$ \\
\hline \multicolumn{2}{|l|}{ Tobacco } \\
\hline Yes & $81(20.4)$ \\
\hline No & $317(79.6)$ \\
\hline \multicolumn{2}{|l|}{ Marijuana } \\
\hline Yes & $42(10.6)$ \\
\hline No & $356(89.4)$ \\
\hline \multicolumn{2}{|l|}{ Cocaine } \\
\hline Yes & $8(2.0)$ \\
\hline No & $390(98.0)$ \\
\hline \multicolumn{2}{|l|}{ Amphetamines or ecstasy } \\
\hline Yes & $9(2.3)$ \\
\hline No & $389(97.7)$ \\
\hline \multicolumn{2}{|l|}{ Inhalants } \\
\hline Yes & $21(5.3)$ \\
\hline No & $377(94.7)$ \\
\hline \multicolumn{2}{|l|}{ Hypnotics/sedatives } \\
\hline Yes & $11(2.8)$ \\
\hline No & $387(97.2)$ \\
\hline \multicolumn{2}{|l|}{ Hallucinogens } \\
\hline Yes & $11(2.8)$ \\
\hline No & $387(97.2)$ \\
\hline \multicolumn{2}{|l|}{ Opiates } \\
\hline Yes & $5(1.3)$ \\
\hline No & $393(98.7)$ \\
\hline
\end{tabular}


Table 2. Bivariate and multivariate Poisson regression models for legal drug use at least once in life among university students according to independent variables

\begin{tabular}{|c|c|c|c|c|c|c|}
\hline \multirow{3}{*}{ Variables } & \multicolumn{2}{|c|}{ Legal drug use } & \multirow{2}{*}{\multicolumn{2}{|c|}{$\begin{array}{c}\text { Bivariate } \\
\text { Unadjusted } \mathbf{P R}^{\star}\end{array}$}} & \multirow{2}{*}{\multicolumn{2}{|c|}{$\begin{array}{c}\text { Multivariate } \\
\text { Adjusted } \mathbf{P R}^{\star \star}\end{array}$}} \\
\hline & \multirow{2}{*}{$\frac{\text { No }}{\mathrm{n}(\%)}$} & \multirow{2}{*}{$\begin{array}{c}\text { Yes } \\
\mathrm{n}(\%)\end{array}$} & & & & \\
\hline & & & $(95 \% \mathrm{CI})$ & p-value & $(95 \% \mathrm{CI})$ & p-value \\
\hline \multicolumn{7}{|l|}{ Sex } \\
\hline Female & $116(54.5)$ & $97(45.5)$ & 1.00 & & 1.00 & \\
\hline Male & $58(31.4)$ & $127(68.6)$ & $1.50(1.26-1.79)$ & $<0.001$ & $1.48(1.25-1.76)$ & $<0.001$ \\
\hline \multicolumn{7}{|l|}{ Age group } \\
\hline$\leq 21$ years & $93(51.4)$ & $88(48.6)$ & 1.00 & & 1.00 & \\
\hline$>21$ years & $81(37.3)$ & $136(62.7)$ & $1.28(1.07-1.54)$ & 0.006 & $1.23(1.03-1.47)$ & 0.021 \\
\hline \multicolumn{7}{|l|}{ Marital status } \\
\hline Single & $148(44.8)$ & $182(55.2)$ & 1.00 & & - & - \\
\hline Married/Divorced & $26(38.8)$ & $41(61.2)$ & $1.11(0.89-1.37)$ & 0.341 & - & - \\
\hline \multicolumn{7}{|l|}{ Ethnicity } \\
\hline Caucasian & $67(41.4)$ & $95(58.6)$ & $1.07(0.90-1.27)$ & 0.428 & - & - \\
\hline Non-Caucasian & $107(45.3)$ & $129(54.7)$ & 1.00 & & - & - \\
\hline \multicolumn{7}{|l|}{ Family income } \\
\hline$<3$ times BMMW & $132(45.4)$ & $159(54.6)$ & 1.00 & & - & - \\
\hline$\geq 3$ times BMMW & $41(38.7)$ & $65(61.3)$ & $1.12(0.93-1.34)$ & 0.219 & - & - \\
\hline \multicolumn{7}{|l|}{ Paid work } \\
\hline No & $113(50.0)$ & $113(50.0)$ & 1.00 & & - & - \\
\hline Yes & $61(35.5)$ & $111(64.5)$ & $1.29(1.08-1.53)$ & 0.003 & - & - \\
\hline \multicolumn{7}{|l|}{ Resides with parents } \\
\hline No & $45(33.1)$ & $91(66.9)$ & $1.31(1.11-1.55)$ & 0.001 & $1.20(1.01-1.41)$ & 0.031 \\
\hline Yes & $129(49.2)$ & $133(50.8)$ & 1.00 & & 1.00 & \\
\hline \multicolumn{7}{|l|}{ Religion } \\
\hline No & $23(26.1)$ & $65(73.9)$ & $1.44(1.22-1.69)$ & $<0.001$ & $1.37(1.16-1.62)$ & $<0.001$ \\
\hline Yes & $151(48.7)$ & $159(51.3)$ & 1.00 & & 1.00 & \\
\hline \multicolumn{7}{|l|}{ Course } \\
\hline Health sciences & $32(36.4)$ & $56(63.6)$ & $1.23(0.99-1.53)$ & 0.054 & $1.33(1.08-1.64)$ & 0.007 \\
\hline Exact sciences & $60(42.6)$ & $81(57.4)$ & $1.11(0.91-1.36)$ & 0.292 & $1.14(0.94-1.39)$ & 0.166 \\
\hline Human sciences & $82(48.5)$ & $87(51.5)$ & 1.00 & & 1.00 & \\
\hline \multicolumn{7}{|l|}{ Classes } \\
\hline Morning/Afternoon & $111(48.1)$ & $120(51.9)$ & 1.00 & & - & - \\
\hline Night & $63(37.7)$ & $104(62.3)$ & $1.19(1.01-1.42)$ & 0.038 & - & - \\
\hline \multicolumn{7}{|l|}{ Period } \\
\hline First year & $98(47.8)$ & $107(52.2)$ & 1.00 & & - & - \\
\hline Last year & $76(39.4)$ & $117(60.6)$ & $1.16(0.97-1.38)$ & 0.091 & - & - \\
\hline
\end{tabular}

PR: prevalence ratio; CI: confidence interval; BMMW: Brazilian monthly minimum wage. ${ }^{\star}$ Unadjusted Poisson regression for independent variables and legal drug use at least once in life. ${ }^{*}$ Variables incorporated into multivariate model $(p<0.20)$ : sex, age group, paid work, residing with parents, religion, course, time of day in which classes are concentrated and period of course

\section{DISCUSSION}

Studies on the use of legal and street drugs have revealed important data on the situation in Brazil. However, investigations that seek to evaluate factors associated with drug use remain scarce, despite the fact that individuals who take drugs have the potential to develop hazardous use. Thus, the present findings can contribute toward the prioritization of prevention programs for population groups at risk of drug abuse. The prevalence of legal and street drug use in life was similar to that found in the first household survey on drug use in Brazil ${ }^{11}$. First contact with drugs occurs at an increasingly early age and can contribute to the development of risk consumption.

Alcohol, tobacco and marijuana were the most frequent drugs reported by the students, which is in agreement with other studies involving the university population ${ }^{1,12,13}$. The male sex and an older age were associated with the use of legal and street drugs in life, which is also in agreement with data described in previous studies ${ }^{12,14,15}$. Silva and Tucci ${ }^{5}$ report that the association between the male sex and risk use may be because males are given freedom and independence at an earlier age, which facilitates 
Table 3. Bivariate and multivariate Poisson regression models for street drug use at least once in life among university students according to independent variables

\begin{tabular}{|c|c|c|c|c|c|c|}
\hline \multirow{3}{*}{ Variables } & \multicolumn{2}{|c|}{ Street drug use } & \multirow{2}{*}{\multicolumn{2}{|c|}{$\begin{array}{c}\text { Bivariate } \\
\text { Unadjusted } \mathbf{P R}^{*}\end{array}$}} & \multirow{2}{*}{\multicolumn{2}{|c|}{$\begin{array}{c}\text { Multivariate } \\
\text { Adjusted } \mathbf{P R}^{\star \star}\end{array}$}} \\
\hline & \multirow{2}{*}{$\begin{array}{c}\text { No } \\
\mathbf{n}(\%)\end{array}$} & \multirow{2}{*}{$\begin{array}{c}\text { Yes } \\
\mathrm{n}(\%)\end{array}$} & & & & \\
\hline & & & $(95 \% \mathrm{CI})$ & p-value & $(95 \% \mathrm{CI})$ & p-value \\
\hline \multicolumn{7}{|l|}{ Sex } \\
\hline Female & $196(92.0)$ & $17(8.0)$ & 1.00 & & 1.00 & \\
\hline Male & $149(80.5)$ & $36(19.5)$ & $2.43(1.41-4.19)$ & 0.001 & $2.33(1.35-4.02)$ & 0.002 \\
\hline \multicolumn{7}{|l|}{ Age group } \\
\hline$\leq 21$ years & $167(92.3)$ & $14(7.7)$ & 1.00 & & 1.00 & \\
\hline$>21$ years & $178(82.0)$ & $39(18.0)$ & $2.32(1.30-4.14)$ & 0.004 & $2.27(1.28-4.02)$ & 0.005 \\
\hline \multicolumn{7}{|l|}{ Marital status } \\
\hline Single & $287(87.0)$ & $43(13.0)$ & 1.00 & & - & - \\
\hline Married/Divorced & $57(85.1)$ & $10(14.9)$ & $1.14(0.60-2.16)$ & 0.676 & - & - \\
\hline \multicolumn{7}{|l|}{ Ethnicity } \\
\hline Caucasian & $143(88.3)$ & 19(11.7) & 1.00 & & - & - \\
\hline Non-Caucasian & $202(85.6)$ & $34(14.4)$ & $1.22(0.72-2.07)$ & 0.442 & - & - \\
\hline \multicolumn{7}{|l|}{ Family income } \\
\hline$<3$ times BMMW & $259(89.0)$ & $32(11.0)$ & 1.00 & & 1.00 & \\
\hline$\geq 3$ times BMMW & $85(80.2)$ & $21(19.8)$ & $1.80(1.08-2.98)$ & 0.022 & $1.73(1.05-2.85)$ & 0.030 \\
\hline \multicolumn{7}{|l|}{ Paid work } \\
\hline No & 202(89.4) & $24(10.6)$ & 1.00 & & - & - \\
\hline Yes & $143(83.1)$ & $29(16.9)$ & $1.58(0.96-2.62)$ & 0.072 & - & - \\
\hline \multicolumn{7}{|l|}{ Resides with parents } \\
\hline No & $109(80.1)$ & 27(19.9) & $2.00(1.21-3.28)$ & 0.006 & - & - \\
\hline Yes & $236(90.1)$ & $26(9.9)$ & 1.00 & & - & - \\
\hline \multicolumn{7}{|l|}{ Religion } \\
\hline No & $69(78.4)$ & 19(21.6) & $1.96(1.18-3.27)$ & 0.009 & $1.70(1.02-2.84)$ & 0.040 \\
\hline Yes & $276(89.0)$ & $34(11.0)$ & 1.00 & & 1.00 & \\
\hline \multicolumn{7}{|l|}{ Course } \\
\hline Health sciences & $73(83.0)$ & $15(17.0)$ & $1.51(0.81-2.83)$ & 0.193 & - & - \\
\hline Exact sciences & $122(86.5)$ & $19(13.5)$ & $1.19(0.66-2.17)$ & 0.551 & - & - \\
\hline Human sciences & $150(88.8)$ & 19(11.2) & 1.00 & & - & - \\
\hline \multicolumn{7}{|l|}{ Classes } \\
\hline Morning/Afternoon & $202(87.4)$ & $29(12.6)$ & 1.00 & & - & - \\
\hline Night & $143(85.6)$ & $24(14.4)$ & $1.14(0.69-1.89)$ & 0.598 & - & - \\
\hline \multicolumn{7}{|l|}{ Period } \\
\hline First year & $181(88.2)$ & $24(11.7)$ & 1.00 & & - & - \\
\hline Last year & $164(85.0)$ & $29(15.0)$ & $1.28(0.77-2.12)$ & 0.332 & - & - \\
\hline
\end{tabular}

PR: prevalence ratio; CI: confidence interval; BMMW: Brazilian monthly minimum wage. ${ }^{*}$ Unadjusted Poisson regression for independent variables and street drug use at least once in life. ${ }^{* *}$ Variables incorporated into multivariate model $(\mathrm{p}<0.20)$ : sex, age group, family income, paid work, residing with parents, religion and course

the onset of drug use in public places ${ }^{16}$. Thus, it is important to establish programs directed at this group in an attempt to avoid first contact or minimize harmful effects.

A higher monthly income was associated with street drug use in life. Moreover, not living with one's parents favored the use of legal drugs. These characteristics may result from a better socioeconomic status. A previous study reports that the risk of drug use increases when the parents are separated or when young individuals live with other people, which are considered strong indicators for the emergence of psychoactive drug use ${ }^{17}$. Adapting to life outside the family environment contributes to independence as a consequence of the lack of parental supervision ${ }^{18}$. Moreover, a higher family income has been reported to be a risk factor for greater alcohol intake ${ }^{19}$, likely due to greater access to locations of frequent use as well as greater purchasing power.

Religion was considered a protection factor. Students who followed a religion were less prone to experiment with either legal or street drugs. Indeed, studies have demonstrated that individuals who practice a religion belong to a group with 
established, shared values and norms ${ }^{12,20,21}$. Thus, the effects of religiousness on drug use may be mediated by better self-control and less tolerance for deviant behavior ${ }^{2,22}$. Cultural agents therefore have the potential to affect drug use and the social norms or practices that govern the use of specific substances within a given culture ${ }^{23,24}$.

A greater prevalence rate of street drug use in life was found among students in courses in the health field. It should be stressed that students in the health field could one day go on to become involved in drug prevention and treatment programs $\mathrm{s}^{25,26}$. Thus, despite scientific knowledge on the consequences of drug use, other factors must be involved in this habit. This relationship may be explained by the fact that students in the health field have a clinical component in their curriculum, which can increase the level of stress, leading to a greater frequency of the use of psychoactive substances ${ }^{27}$. However, this relationship has not been fully clarified and more specific studies are needed.

No significant differences were found between students at the beginning and end of their courses with regard to drug use in life. It is possible that drug use tends to begin at increasingly younger ages, as demonstrated in studies involving schoolchildren ${ }^{14,21}$.

The present study has limitations inherent to the cross-sectional design and the memory of participants, as information bias may have occurred at the time of filling out the questionnaire, such as the time since the last use of drugs and the fear of having personal responses published. However, measures were taken to minimize possible errors, such as the use of validated questionnaires and the execution of a pilot study. Moreover, students were instructed regarding the questions and were assured of the confidentiality of their answers. Self-administered questionnaire in the classroom setting is the most widely employed method for the evaluation of the prevalence of substance use among university students due to the better cost-benefit relationship, the low number of refusals and the assurance of anonymity.

Users of psychoactive drugs generally only seek healthcare services in more advanced stages of substance abuse. However, early intervention, even prior to initiating a habit, can exert an influence on healthy choices by individuals, as the use of psychoactive drugs directly affects health and academic performance ${ }^{28}$. The results of the present study could be used to understand what population groups are vulnerable to the use of legal and street drugs. Awareness and prevention policies directed at specific groups are the most successful actions, such as providing information and strategies for coping with stress as well as training programs for professors to facilitate the early detection of drug use.

\section{REFERENCES}

1. Chiapetti N, Serbena CA. Alcohol, tobacco and other drugs used by students of health services from a University in Curitiba. Psicol Reflex Crit. 2007;20(2):303-13. http://dx.doi.org/10.1590/S0102-79722007000200017.

2. Gomes FC, Andrade AG, Izbicki R, Moreira Almeida A, Oliveira LG. Religion as a protective factor against drug use among Brazilian university students: a national survey. Rev Bras Psiquiatr. 2013;35(1):29-37. http:// dx.doi.org/10.1016/j.rbp.2012.05.010. PMid:23567597.

3. Silva AC, Lucchese R, Vargas LS, Benício PR, Vera I. Application of the Alcohol, Smoking and Substance Involvement Screening Test (ASSIST) instrument: an integrative review. Rev Gaúcha Enferm. 2016;37(1):e52918. http://dx.doi.org/10.1590/1983-1447.2016.01.52918. PMid:27074305.

4. Pereira DS, Souza RS, Buaiz V, Siqueira MM. Psychoactive substance use among medicine students from Espirito Santo Federal University. J Bras Psiquiatr. 2008;57(3):188-95. http://dx.doi.org/10.1590/S004720852008000300006

5. Silva ÉC, Tucci AM. Pattern of alcohol consumption in college students (freshmen) and gender differences. Temas Psicol. 2016;24(1):313-23. http:// dx.doi.org/10.9788/TP2016.1-21

6. Silva DAS, Petroski EL. The simultaneous presence of health risk behaviors in freshman college students in Brazil. J Community Health. 2012;37(3):5918. http://dx.doi.org/10.1007/s10900-011-9489-9. PMid:21979565.

7. Mallett KA, Marzell M, Turrisi R. Is reducing drinking always the answer to reducing consequences in first-year college students? J Stud Alcohol
Drugs. 2011;72(2):240-6. http://dx.doi.org/10.15288/jsad.2011.72.240. PMid:21388597.

8. Frankfort-Nachimias C, Nachimias D. Research methods in the social sciences. London, Arnold; 1992

9. WHO ASSIST Working Group. The Alcohol, Smoking and Substance Involvement Screening Test (ASSIST): development, reliability and feasibility. Addiction. 2002;97(9):1183-94. http://dx.doi.org/10.1046/j.13600443.2002.00185.x. PMid:12199834

10. Henrique IFS, De Micheli D, Lacerda RB, Lacerda LA, Formigoni ML. Validation of the Brazilian version of Alcohol, Smoking and Substance Involvement Screening Test (ASSIST). Rev Assoc Med Bras. 2004;50(2):199206. http://dx.doi.org/10.1590/S0104-42302004000200039. PMid:15286871.

11. Galduróz JC, Noto AR, Nappo SA, Carlini EA. Use of psychotropic drugs in Brazil: household survey in the 107 biggest Brazilian cities--2001. Rev Lat Am Enfermagem. 2005;13(special number):888-95. PMid:16400456.

12. Silva LV, Malbergier A, Stempliuk VA, Andrade AG. Factors associated with drug and alcohol use among university students. Rev Saude Publica. 2006;40(2):280-8. http://dx.doi.org/10.1590/S0034-89102006000200014. PMid:16583039.

13. Petroianu A, Reis DCF, Cunha BDS, Souza DM. Prevalence of alcohol, tobacco and psychotropic drug consumption by medical students of the “Universidade Federal de Minas Gerais”. Rev Assoc Med Bras. 2010;56(5):56871. http://dx.doi.org/10.1590/S0104-42302010000500019. PMid:21152830. 
14. Backes DS, Zanatta FB, Costenaro RS, Rangel RF, Vidal J, Kruel CS, et al. Risk indicators associated with the consumption of illicit drugs by schoolchildren in a community in the south of Brazil. Cien Saude Colet. 2014;19(3):899-906. http://dx.doi.org/10.1590/1413-81232014193.00522013. PMid:24714904.

15. Elicker E, Palazzo LS, Aerts DRGC, Alves GG, Câmara S. Use of alcohol, tobacco and other drugs by adolescents students from Porto Velho-RO, Brazil. Epidemiol Serv Saude. 2015;24(3):399-410.

16. Wood JT. Gendered lives: communication, gender, and culture. Belmont: Wadsworth Publishing; 1997.

17. Baus J, Kupek E, Pires M. Prevalence and risk factors associated with drug use among school students, Brazil. Rev Saude Publica. 2002;36(1):40-6. http://dx.doi.org/10.1590/S0034-89102002000100007. PMid:11887228.

18. Galduróz JC, Sanchez ZM, Opaleye ES, Noto AR, Fonseca AM, Gomes PLS, et al. Factors associated with heavy alcohol use among students in Brazilian capitals. Rev Saude Publica. 2010;44(2):267-73. PMid:20339625.

19. Andrade AG, Duarte PCAV, Barroso LP, Nishimura R, Alberghini G, Oliveira LG. Use of alcohol and other drugs among Brazilian college students: effects of gender and age. Rev Bras Psiquiatr. 2012;34(3):294-305. http://dx.doi. org/10.1016/j.rbp.2012.02.002. PMid:23429775.

20. Granville-Garcia AF, Clementino MA, Gomes MNC, Firmino RT, Ribeiro GLA, Siqueira MBLD. Alcohol consumption among adolescents: attitudes, behaviors and associated factors. Cien Saude Colet. 2014;19(1):7-16. http:// dx.doi.org/10.1590/1413-81232014191.1989. PMid:24473598.

21. Granville-Garcia AF, Sarmento DJ, Santos JA, Pinto TA, Sousa RV, Cavalcanti AL. Smoking among undergraduate students in the area of health. Cien Saude Colet. 2012;17(2):389-96. http://dx.doi.org/10.1590/ S1413-81232012000200013. PMid:22267034.
22. Walker C, Ainette MG, Wills TA, Mendoza D. Religiosity and substance use: test of an indirect-effect model in early and middle adolescence. Psychol Addict Behav. 2007;21(1):84-96. http://dx.doi.org/10.1037/0893164X.21.1.84. PMid:17385958.

23. Zeferino MT, Hamilton H, Brands B, Wright MGM, Cumsille F, Khenti A. Drug consuption among university students: family, spirituality and entertainment moderating influence of pairs. Texto Contexto Enferm. 2015;24(spe):125-35. http://dx.doi.org/10.1590/0104-07072015001150014.

24. Burdzovic Andreas J, Pape H, Bretteville-Jensen AL. Who are the adolescents saying "No" to cannabis offers. Drug Alcohol Depend. 2016;163(1):64-70. http://dx.doi.org/10.1016/j.drugalcdep.2016.03.025. PMid:27107848.

25. Puig-Nolasco A, Cortaza-Ramirez L, Cristina Pillon S. Alcohol use among Mexican medical students. Rev Lat Am Enfermagem. 2011;19(spe):714-21. http://dx.doi.org/10.1590/S0104-11692011000700008. PMid:21739052.

26. Cardoso FM, Barbosa HA, Costa FM, Vieira MA, Caldeira AP. Factors associated with practice of binge drinking among students of health. Rev CEFAC. 2015;17(2):475-84. http://dx.doi.org/10.1590/1982-021620158914.

27. Al-Sayed AA, Al-Rashoudi AH, Al-Eisa AA, Addar AM, Al-Hargan A, Al-Jerian AA, et al. Sedative drug use among king saud university medical students: a cross-sectional sampling study. Depress Res Treat. 2014;2014:378738. http://dx.doi.org/10.1155/2014/378738. PMid:24551449.

28. Suerken CK, Reboussin BA, Egan KL, Sutfin EL, Wagoner KG, Spangler $\mathrm{J}$, et al. Marijuana use trajectories and academic outcomes among college students. Drug Alcohol Depend. 2016;162(1):137-45. http://dx.doi. org/10.1016/j.drugalcdep.2016.02.041. PMid:27020322.

Received on: Mar. 20, 2017

Accepted on: Feb 21, 2018 